\title{
Od futurysty do mocarstwowca. Przypadek Stanisława Grędzińskiego
}

\author{
Aleksander Wójtowicz
}

TEKSTY DRUGIE 2021, NR 3, S. 290-304

DOI: 10.18318/td.2021.3.19 | ORCID: 0000-0003-0436-1965

C ałe życie ludzkie to walka, walka jest właściwym sensem życia, jest istotnym sposobem bytowania i cokolwiek walką nie jest, jest rozkładem, marazmem, zgnilizną, nikczemnością. Wojna zaś jest najszlachetniejszą formą walki, jest szczytowym punktem życia-walki", pisał w ogłoszonym na łamach "Mocarstwowca" artykule Prawda o wojnie (1930) Stanisław Grędziński. Zaraz potem dodawał: „W gruncie rzeczy tak zwany pokój jest to tylko pewne stadium wojny, stadium wstępne, gdy dusze ludzkie gotują się, by wystrzelić wspaniałym, oczyszczającym płomieniem ofiarnym, gromadzą na ów moment wielki materialne i moralne siły - podtrzymując w głębi serca żar namiętnego zapału". Tak ostentacyjna pochwała wojny dorównywała zuchwałością deklaracjom Filippa Tomassa Marinettiego, który dwadzieścia lat wcześniej stwierdzał z podobną emfazą w Manifeściefuturyzmu, że ,jedynie walka jest piękna”, a wojna to „jedyna higiena świata”.

1 S. Grędziński Prawda o wojnie, "Mocarstwowiec" $1930 \mathrm{nr} 7$.

2 F.T. Marinetti Akt założycielski i manifest futuryzmu, w: Ch. Baumgarth Futuryzm, przeł. J. Tasarski, WAiF, Warszawa 1987, s. 31-38. Na

\section{Aleksander}

Wójtowicz - dr hab., historyk literatury, edytor, adiunkt $w$ Zakładzie Literatury XX i XXI wieku Instytutu Filologii Polskiej UMCS. Zajmuje się dziejami europejskich ruchów awangardowych, współczesną sztuką eksperymentalną oraz edytorstwem literatury XX w. Autor książek Cogito $i_{\text {„,sejsmograf }}$ podświadomości."Proza Pierwszej Awangardy (2010), Nowa Sztuka. Początki (i końce) (2017) i Epoka wielkiego zamętu. Szkice o literaturze nowoczesnej (1918-1939) (2020). 
Zbieżność nie była zresztą przypadkowa, gdyż Grędziński w pierwszej połowie lat 20. był aktywnym poetą futurystycznym. W 1926 roku opublikował debiutancki tom Parabole, po czym zarzucił literaturę i zgłosił akces do założonej rok wcześniej Legii Mocarstwowej, stając się z miejsca jej najbardziej zagorzałym publicystą. Ewolucja jego poglądów wpisała się zatem w dość charakterystyczną dla tego etapu nowoczesności figurę artysty awangardowego, który postrzegał swoje miejsce w społeczeństwie przez pryzmat napięcia między sztuką a praktyką życiową ${ }^{3}$ Inaczej jednak niż w wypadku wielu twórców - poczynając od włoskich futurystów, przez radzieckich konstruktywistów aż po francuskich surrealistów - Grędziński definitywnie porzucił sztukę na rzecz polityki, wychodząc z założenia, że tylko na gruncie tej drugiej zdoła wcielić wyznawane przez siebie idee w życie. Z dzisiejszej perspektywy wyraźnie widać, że rama dyskursywna jego wystąpień publicystycznych ufundowana została na zespole pojęć i wyobrażeń wytworzonych dwie dekady wcześniej w dziedzinie estetyki. Jej zręby ukształtował - by przywołać tytuł książki Marjorie Perloff - „futurystyczny moment” (futurist moment) ${ }^{4}$, który najdobitniej doszedł do głosu w wystąpieniach Marinettiego i jego naśladowców, natomiast w szerszym wymiarze pobrzmiewał w deklaracjach całej ówczesnej formacji awangardowej, przejawiając się w utopijno-profetycznym przekonaniu o nieuchronnym i rewolucyjnym charakterze nadchodzących zmian. Destrukcyjny impuls patronował nie tylko dadaistycznym i surrealistycznym rewoltom - za jego sprawą do ówczesnej kultury przenikały także tak problematyczne z perspektywy wydarzeń następnych lat elementy "protofaszystowskie" (czy szerzej: protototalitarne)

W tym kierunku ciążyły poglądy Grędzińskiego, co uwyraźniło się na początku lat 30., kiedy po zarzuceniu literatury na rzecz działalności politycznej

temat politycznego i militarnego zaangażowania futurystów włoskich zob. S. Daly Italian futurism and the First World War, University of Toronto Press, Toronto 2016; W.L. Adamson Modernism and fascism: the politics of culture in Italy, 1903-1922, "The American Historical Review" 1990 no. 2; A. Bowler, Politics as art: Italian futurism and fascism, "Theory and Society" 1991 no. 6.

3 P. Bürger Teoria awangardy, przeł. J. Kita-Huber, Universitas, Kraków 2006.

4 M. Perloff The futurist moment. Avant-garde, avant guerre and the language of rupture, University of Chicago Press, Chicago 1986. Tytuł książki został zaczerpnięty z fragmentu Teorii awangar$d y$ Renata Poggiolego, który pisał, że "futurystyczny moment należy do całej awangardy, a nie tylko do ruchu pod tą nazwą", twierdząc, iż "ów ruch był tylko symptomem głębszego i bardziej rozległego stanu umysłu". R. Poggioli The theory of the avant-garde, trans. G. Fitzderald, Harvard University Press, Massachusetts 1968, s. 68-69.

5 M. Perloff The futurist moment, s. 7. 
postulował, aby demokrację parlamentarną zastąpić rządami autorytarnymi, społeczeństwo cywilne - zmilitaryzowanym, „nihilistyczne” wzorce - moralnością katolicką, edukację szkolną - biopolityczną tresurą ciała, a dyplomatyczne relacje z sąsiadami - hasłami ekspansji politycznej i kulturowej.

W jaki sposób futurystyczny poeta został piewcą idei mocarstwowych? Odpowiedź na to pytanie utrudniają znaczne luki w biografii Grędzińskiego ${ }^{6}$. Wiadomo, że urodził się w 1895 roku w Lublinie, w 1913 roku podjął studia politechniczne we Lwowie, gdzie wstąpił też do Związku Strzeleckiego, w następnych latach brał zaś udział w Wielkiej Wojnie jako żołnierz Legionów, których szeregi opuścił jako inwalida w 1917 (po roku wrócił na pole walki jako artylerzysta). Po odzyskaniu przez Polskę niepodległości podejmował w różnych miastach studia prawnicze, medyczne, polonistyczne oraz z zakresu sztuk pięknych, lecz żadnych nie udało mu się ukończyć. W czasie pobytu w Krakowie z bliska przyglądał się działalności tamtejszych futurystów, których hasła przeniósł następnie na grunt lubelski, stając się jednym z czołowych twórców grupy literackiej skupionej wokół czasopisma "Reflektor". Wyróżniał się w niej ekscentrycznym sposobem bycia, który zyskał mu lokalną sławę oraz zapewnił przydomek „Mefistofelesa we fraku”. W 1926 roku ukazał się jego debiutancki tom - Parabole, do którego okładkę zaprojektował związany z formistami malarz Kazimierz Tomorowicz.

W tym samym czasie Grędziński rozpoczął karierę publicysty na łamach „Ziemi Lubelskiej”; w cyklu „Zielony Reflektor” ogłaszał tam felietony poświęcone sprawom lokalnym oraz przemianom w zakresie ówczesnej obyczajowości ${ }^{8}$.W 1927 roku zarzucił twórczość poetycką i przeniósł się do Warszawy, podjął tam współpracę z redakcją piłsudczykowskiej „Drogi”, próbując sił jako krytyk oraz tłumacz. Następnie - co z perspektywy niniejszego szkicu szczególnie istotne - zaangażował się w działalność Legii Mocarstwowej i redagował związane z nią czasopisma: „Mocarstwowca” (wraz z dodatkiem

6 Pierwszy (i w zasadzie najpełniejszy) biogram Grędzińskiego znajduje się w Antologii współczesnych poetów lubelskich, red. ks. L. Zalewski, Towarzystwo Przyjaciół Nauk, Lublin 1939, s. 174. Zob. także T. Kłak Przypomnienia (Grędziński - Michalski - Rzeczyca), w: tegoż Drogami Czechowicza, Wydawnictwo KUL, Lublin 2010, s. 161-165. W. Gralewski Mefistofeles we fraku, w: tegoż Ogniste koła, Wydawnictwo Lubelskie, Lublin 1963.

8 Zob. S. Grędziński Zielony Reflektor (wybór), oprac. M. Sikora, „Artes Humanae” 2018 nr 2, s. 211-221.

9 Na łamach „Drogi” (1929 nr 1) Grędziński opublikował przekład noweli Dialog ceni Georges'a Bernanosa wraz z krótkim szkicem na temat twórczości francuskiego pisarza pod tytułem /erzy Bernanos. 
"Młody Mocarstwowiec”) oraz „Głos Fabryczny”. Na tym w zasadzie kończą się pewne informacje, a zaczynają „,białe plamy”: nie można zrekonstruować ostatnich lat życia Grędzińskiego, nieznane są jego losy w czasie wojny, podobnie zresztą jak data jego śmierci. Co więcej, nie wiadomo nawet jak wyglądał, w lubelskich archiwach ani w "mocarstwowej” prasie nie zachowała się żadna jego fotografia.

Węzłowym punktem biografii Grędzińskiego była rezygnacja z twórczości literackiej. Gest ten trudno rozpatrywać w kontekście artystycznych mitologii wysokiego modernizmu, gdy „złamanie pióra” było przedstawiane jako dramatyczny akt odwrócenia się od epoki nowoczesnej ${ }^{10}$. W tym wypadku sytuacja prezentowała się w sposób zgoła odmienny; Grędziński przecież zamilkł jako poeta, a zaczął mówić jako publicysta, a w jego artykułach wciąż pobrzmiewały argumenty właściwe dla dyskursu futurystycznego. Poza polem sztuki nabierały jednak innego charakteru, podobnie zresztą jak stało się we Włoszech, gdzie Marinetti (wraz z naśladowcami) wysunął projekt estetyzacji życia politycznego, w którym centralne miejsce zajmowała wojna, co umożliwiło „skoncentrowanie ruchów masowych o największym zasięgu na celu, który bezpośrednio nie zagraża tradycyjnym stosunkom własności"11. W orbicie podobnych założeń kształtowały się poglądy Grędzińskiego, który z dużą niechęcią wypowiadał się o sporach politycznych i partyjnych niesnaskach, uznając je za zupełnie nieistotne w zestawieniu z imperatywem budowania mocarstwa ${ }^{12}$. Wystarczającym lekarstwem na ekonomiczne kłopoty kraju był dla niego solidaryzm społeczny, który zresztą propagował redagowany przez niego "Głos Fabryczny" (winieta pisma zawierała hasło: „Niech żyje solidaryzm zawodowy - precz z walką klas”).

Grędziński patrzył na czasy współczesne z perspektywy weterana. Optyka taka narzucała zupełnie inną hierarchię spraw bieżących, pisał o nich tak, jakby rozbrat z polem bitwy był jedynie tymczasowy, a powrót na nie - nieuchronny. Gdy w jego wywodach pobrzmiewały echa legionowego etosu z czasów Wielkiej Wojny, to zazwyczaj nie patronował im impuls nostalgiczny, lecz przekonanie o potrzebie wytwarzania odpowiednich wzorców dla

M. Piech O autorze i jego wierszach, w: S. Grędziński Parabole, red. M. Piech, Wydawnictwo KUL, Lublin 2015, s. 86.

11 W. Benjamin Dzieło sztuki w dobie reprodukcji technicznej, przeł. J. Sikorski, w: tegoż Twórca jako wytwórca, przeł. H. Orłowski, J. Sikorski (z niem.), S. Pieczara (z fr.), Wydawnictwo Poznańskie, Poznań 1975, s. 94. 
młodzieży, która niedługo będzie musiała wziąć udział w walce zbrojnej. Argumenty o jej nieuchronności wsparte były na charakterystycznym dla wielu ówczesnych dyskursów o wojnie przeświadczeniu, że konflikt zbrojny jest jedynym sposobem na obronę rodzimej kultury przed zagrożeniem ze strony innych państw ${ }^{13}$. Dlatego w centrum głoszonych na łamach "Mocarstwowca” haseł znajdowała się triada: imperium, militaryzm, ekspansja.

Przyświecały one działalności Związku Pracy Mocarstwowej. Geneza organizacji była związana zarówno z coraz powszechniej odczuwanym kryzysem parlamentaryzmu, jak i szerszymi przekształceniami w obrębie polskiej myśli konserwatywnej, gdy zaczęło ją wyznawać nowe pokolenie. Jego reprezentanci byli sceptycznie nastawieni do poglądów poprzedników, a rdzeń ich koncepcji stanowiło przekonanie, że imperializm „był naturalnym dążeniem każdego zdrowego państwa" ${ }^{14}$. Z tego względu po przewrocie majowym stali się zagorzałymi zwolennikami rządów sanacyjnych, wychodząc z założenia, że jedynie rządy autorytarne zdołają wprowadzić w życie hasło „Polska - Mocarstwowa”. Partie opozycyjne uznawali za przeszkody stojące na drodze do realizacji tego celu, dlatego w zdecydowany sposób krytykowali zarówno komunistów, socjalistów, jak i endecję, zarzucając tej ostatniej krótkowzroczny nacjonalizm.

Deklaracja ideowa stanowiła katalog snów o potędze. Była tam mowa o misji dziejowej polegającej na „stworzeniu z Polski Mocarstwa”, o „życiowej konieczności" zapewnienia jej dostępu do morza oraz zamorskich kolonii, wreszcie - o „mocnej konstrukcji hierarchicznych władz administracyjnych z nadrzędnym stanowiskiem Głowy Państwa"15. W dyskursie mocarstwowym stosowano kategorie „nowości” i „tradycji”; pierwsza z nich była wyraźnie dostrzegalna w stwierdzeniu, że „stałe dążenie do lepszego jutra nie pozwala na zasklepienie się w starych formach ustroju społecznego, nie odpowiadającego współczesnej rzeczywistości". Druga natomiast legitymizowała te idee przez powołanie się na „świetną i wielką pamięć Polski Jagiellońskiej, Polski Grunwaldu i Unii, Polski od morza do morza", pobrzmiewała także w haśle

13 towej. Zob. A. Kramer Dynamics of destruction. Culture and mass killing in the First World War,
Oxford University Press, New York 2007, s. 159.

J. Tomasiewicz Naprawa czy zniszczenie demokracji? Tendencje autorytarne i profaszystowskie w polskiej myśli politycznej 1921-1935, Wydawnictwo UŚ, Katowice 2012, s. 112.

5 Deklaracja ideowa „Myśli Mocarstwowej”, w: Konserwatyści polscy 1918-1939. Wybór pism, wprowadzenie i red. M. Król, Wydawnictwa UW, Warszawa 2014, s. 83-85. 
współpracy z innymi krajami słowiańskimi, które powinny się zjednoczyć pod polskim przewodnictwem ${ }^{16}$.

Istotne w tym kontekście były kwestie etniczne. Mocarstwowcy krytykowali nacjonalistów i nawoływali do tolerancji w stosunku do mniejszości narodowych, lecz - co znamienne - nie odnosiło się to do społeczności żydowskiej; z jednej strony potępiali antysemickie wystąpienia jako nieetyczne i bezcelowe, z drugiej natomiast wysuwali dość ogólnikowy postulat „wyodrębnienia kulturalno-narodowego Żydostwa w duchu syjonizmu palestyńskiego"17. W praktyce sprawa była jeszcze o wiele bardziej skomplikowana, gdyż na łamach redagowanego przez Grędzińskiego pisma pobrzmiewały niekiedy akcenty antysemickie.

Mocarstwowcy postrzegali siebie jako organizację „sprężystą i karną”18. Ważne miejsce w ich programie zajmowaly postulaty biopolityczne - kładziono nacisk na konieczność odpowiedniego wyszkolenia i przygotowania do udziału w potencjalnym konflikcie zbrojnym. W tym celu powołano do życia paramilitarną Legię Mocarstwową, w której główną rolę odgrywali Rowmund Piłsudski i Jerzy Giedroyć' ${ }^{19}$. Panowała w niej ścisła dyscyplina oparta na stopniach imitujących hierarchię wojskową: namiestnik, podnamiestnik, regimentarz, podregimentarz, hufcowy, podhufcowy i mocarstwowiec ${ }^{20}$. Jej członkowie brali udział w obozach sportowych i szkoleniach prowadzonych przez zawodowych żołnierzy, współpraca z wojskiem polegała też na tworzeniu ochotniczych formacji (np. I Choragiew Ochotników Ideowych Myśli Mocarstwowej). Równolegle organizacja podejmowała działania o charakterze propagandowym; prowadziła bibliotekę, sekcję teatralną, przygotowywała okolicznościowe akademie, a także powołała do życia miesięcznik, którego pierwszy numer nosił pozornie niewinną nazwę „Żołnierzyk", kolejne zaś o wiele poważniejszą: „Mocarstwowiec. Pismo Legii Mocarstwowej”21.

16 Tamże, s. 83-84.

17 Tamże, s. 84.

18 R. Tomczyk Myśl mocarstwowa. Z dziejów młodego pokolenia II Rzeczypospolitej, Print Group, Szczecin 2008, s. 113.

19 Zob. . Giedroyc Autobiografia na cztery ręce, oprac. K. Pomian, Towarzystwo Opieki nad Archiwum Instytutu Literackiego w Paryżu, Warszawa 2006, s. 35; R. Juchnowski Rowmund Piłsudski (1903-1988). Koncepcje polityczne i społeczne, Wydawnictwo UWr, Wrocław 2009, s. 29-39. Tamże, s. 129.

21 O zmianie nazwy zdecydowała przeprowadzona wśród czytelników ankieta. „Mocarstwowiec” ukazywał się w latach 1929-1932 i byłjednym z kilku wydawanych przez mocarstwowców pism, 
Grędziński był jego czołowym publicystą (a od połowy 1930 również redaktorem). W swoich tekstach przedstawiał Legię jako znak nadejścia nowych czasów, budując dobitne przeciwstawienia między konserwatystami przed- i międzywojennymi: „Tak jak dla Europejczyka taniec murzyński, tak jak dla Murzyna mikroskop, tak też się jawi w atmosferze już tylko egzotycznej, sensacyjnej osobliwości: sport staremu, a filozofia młodemu, optymistyczny realizm jednemu, a mistycyzm cierpiętniczy drugiemu, nastawienie propaństwowe przedwojennemu «patriocie», a bezinteresowny rewolucjonizm młodemu studentowi" ${ }^{22}$. W zbudowanym na zasadzie kontrastu wyliczeniu pobrzmiewało futurystyczne $z$ ducha przekonanie, że winny się zmienić wszystkie zasady porządkujące rzeczywistość. Założeniom tym patronowała nie tylko nowoczesna utopia, dostrzegająca zręby doskonałego świata na horyzoncie przyszłości, lecz także retrotopia ${ }^{23}$, która sięgała korzeniami XVI wieku. Przełom 1918 roku, dowodził Grędziński, odesłał w przeszłość zmurszałe formy z czasów przedwojennych, a równocześnie zburzył „podmurówkę gmachu narodowego sumienia zbudowaną w czasie anarchii szlacheckiej, remontowaną w niewoli”, oraz odsłonił „fundamenty krzepkie, mocarne, mocarstwowe, jagiellońskie, prawenedyjskie, rycerskie, zuchowate, dumne, a co najważniejsze - realne, rzeczywiste" ${ }^{24}$.W enumeracji tej skondensowane zostały kluczowe aspekty mocarstwowej polityki historycznej, która - wbrew wieńczącej cytat tautologii - była konglomeratem mitów (podobnie jak w niemieckim faszyzmie ${ }^{25}$ ). Konsekwencją takiej perspektywy była kontrowersyjna okładka (1930 nr 8), przedstawiająca mapę kraju uwzględniającą wszystkie terytoria, jakie kiedykolwiek znajdowały się pod polskim panowaniem, z wieloznacznym dopiskiem: „O czym każdy mocarstwowiec pamiętać powinien".

Grędziński wytyczał granicę między przeszłością a współczesnością w sposób zbliżony do tego, jaki przewijał się w wypowiedziach całej ówczesnej formacji progresywnej, chętnie posługującej się kontrastowymi

do których należały również "Wiadomości Akademickie”, "Dzień Akademicki”, "Zielona Gromada", "Głos Fabryczny", ,Myśl Mocarstwowa”.

S. Grędziński Między starymi a młodszymi laty, "Mocarstwowiec" $1932 \mathrm{nr} 4$.

Z. Bauman Retrotopia. Jak rządzi nami przeszłość, przeł. K. Lebek, Wydawnictwo Naukowe PWN, Warszawa 2018, s. 13. 
zestawieniami. W tym sensie był zdecydowanym apologetą modernizacji, za której rzeczników uznawał przede wszystkim młode pokolenie, pisał o nim w superlatywach jako o nowej generacji, nieobarczonej skazami przodków, potrafiącej docenić „życie sportowe, utylitaryzm w sztuce, estetykę w życiu powszednim, higienę i zracjonalizowanie trybu życia dla zdrowia ciała, równowagę duchową wobec klęsk życiowych"26. Patronująca tym wywodom narracja o wkraczaniu nowoczesności do społeczeństwa rządzącego się nie tyle nawet tradycjonalistycznymi, ile już przebrzmiałymi zasadami, została zapożyczona z dyskursu futurystycznego, opisującego przejście między „starym” a „nowym" jako moment rewolucyjnego wstrząsu. W takim właśnie tonie Grędziński pisał o „sofistyce «übermanschów» i ponętnym zapachu fleurs du mal à la Przybyszewski", ,tchórzliwych, niedołężnych pięknoduchach z epoki Tetmajerów", a gdzie indziej - komentując prace Komisji Kodyfikacyjnej nad prawem małżeńskim - stwierdzał, że grono to składa się z „, sensualizujących liberalistów, wykarmionych na dekadenckim emocjonalizmie nieboszczki Gabrieli Zapolskiej i na pseudonaukowych wywodach Boya, «mędrca» tego szacownego, żywego jeszcze pomnika chimerycznych zapędów Krakowa z okresu Młodej Polski"27.

Były to dystynkcje typowe dla futurystów. Wyrażały ostentacyjny dystans do paseistycznych norm i wartości, który wyraźnie doszedł również do głosu w debiutanckim tomie Grędzińskiego, pobrzmiewał w nim bowiem wyraźnie duch ówczesnej poezji eksperymentalnej (choć nie tak radykalnej, jak w wystąpieniach innych reprezentantów tego nurtu). Parabole - co znamienne - ciążyły raczej w stronę futuryzmu warszawskiego (Anatol Stern, AleksanderWat) niż krakowskiego (Bruno Jasieński, Tytus Czyżewski), mniej w nich było apoteozy maszyny i techniki, znacznie więcej natomiast pochwały prymitywizmu i witalizmu ${ }^{28}$. Grędzińskiego nie interesowały atrybuty nowoczesnej cywilizacji, niewiele uwagi poświęcał maszynom, ulicznym masom i wytwarzanej dla nich kulturze, chętniej zaś pisał o destrukcyjnej energii

26 S. Grędziński Między starymi a młodszymi laty.

27 [Stanisław Grędziński] Lowelasi przy zielonym stole, "Mocarstwowiec” $1931 \mathrm{nr} 13$. Artykuł ukazał się w rubryce "Reflektor", utworzonej na łamach pisma wkrótce po tym, jak redaktorem został Grędziński. Choć publikowane tam teksty były niepodpisane, można przyjąć, że to właśnie on był autorem, gdyż podobną nazwę nosiła rubryka, w jakiej publikował felietony na łamach "Głosu Lubelskiego" - „Zielony Reflektor" (było to również ewidentne nawiązanie do nazwy grupy poetyckiej, z którą był związany podczas pobytu w Lublinie).

28 Zob. S. Sterna-Wachowiak Miq̨ższ zakazanych owoców: Jankowski, Jasieński, Grędziński (szkice o futuryzmie), Pomorze, Bydgoszcz 1985, s. 125. 
oraz zdobywczych porywach. Motyw podboju przestrzeni (Farys) sąsiadował w jego twórczości z fascynacją mrocznymi stronami życia (Samobójstwo, Skazańcy), brutalistycznymi opisami wybuchu pierwotnych instynktów (Egzotyka), okrucieństwa (Amputacja) oraz akcentami antyreligijnymi (Psalm). Pobrzmiewał w nich charakterystyczny dla twórczości włoskich futurystów impuls antycywilizacyjny, czemu towarzyszyła krytyka zdroworozsądkowego porządkowania świata; „logigeometryczny mózg / to neuroautomat”, stwierdzał podmiot wiersza Metafizyka, a następnie w płynny sposób przechodził do budowania opozycji między niewielką ścieżką oświetlaną przez rozum a bezdrożami, gdzie „wieją olbrzymie, ciemne huragany”. Prowadziło to do mrocznego irracjonalizmu, w którym zacierały się kwestie etyczne i moralne, a na plan pierwszy wysuwało się poszukiwanie „drogi wielkiej i prostej / [...] Drogi Prawdziwej"29, czyli - mówiąc inaczej - apoteoza czynu.

Otwierała ona furtkę między dyskursem futurystycznym a mocarstwowym. W publicystycznych deklaracjach Grędzińskiego dawało się przy tym uchwycić charakterystyczne dla pokolenia Piłsudczyków akcenty romantyczne, utożsamiające „czyn" z działaniem na rzecz ojczyzny, lecz zostały one przytłumione przez ciąg stwierdzeń sytuujących się poza sferą zakreśloną przez hasła Juliusza Kadena-Bandrowskiego oraz licznego grona naśladowców. Grędziński szedł o wiele dalej, w jego wywodach ostry radykalizm przeplatał się z relatywizmem, jak w Prawdzie o wojnie, gdy stwierdzał: „Zasiedziali na swoim dobytku, na rozmaicie zdobytej «krwawicy», łzawią się, że zrabowano im konia albo puszczono z dymem chałupę. Żołnierzowi niosącemu uroczyście życie swoje w ofierze dla ojczyzny w głowie się nie może pomieścić, aby w obliczu rycerskiego jego czynu jakąkolwiek wartość przedstawiały dobra materialne". Po czym dodawał w jeszcze bardziej pryncypialnym tonie: „Historie o gwałtach należy już zaliczyć do rzędu zwykłej blagi, bowiem na ulicach wielkiego miasta co dzień więcej popełniają potwornych gwałtów ludzie uchodzący za przyzwoitych, niż dokonano ich podczas całej wojny"30. Jego wypowiedzi były swoistym negatywem literatury antymilitarnej i pacyfistycznej, zajmowały skrajne miejsce w polu dyskursu o wojnie, rozdartego między wciąż świeżymi wspomnieniami lat 1914-1918 a pierwszymi sygnałami rodzących się totalizmów.

Do publicystyki Grędzińskiego wkradł się cień międzywojennego militaryzmu, wspieranego przez autorytarne władze i potęgowanego przez 
niepokoje społeczne. Widmo wojny totalnej było jednak przesłonięte przez archaiczną retorykę, odwołującą się do etosu rycerskiego, za którego niedościgniony ideał mocarstwowcy uznawali czasy jagiellońskie. Zapatrzony w nie autor deprecjonował wszystkie aspekty wojny mechanicznej, twierdząc, że o zwycięstwie w nadchodzącej wojnie zadecyduje „nie przemysł wojenny, nie liczba, a duch ofensywy, uświadomienie patriotyczne bez kompromisu, bez wahania, nieustępliwe, twarde, dumne, zaborcze"31. Nie sposób jednoznacznie wyrokować, w jakiej mierze była to świadoma strategia propagandowa, w jakiej zaś wytwarzane przez mocarstwowe iluzje przekonania, lecz trudno oprzeć się wrażeniu, że wyobraźnię Grędzińskiego o specyfice działań wojennych oraz polu walki determinowały legionowe doświadczenia $\mathrm{z}$ lat 1914-1918. Spoglądał na wojnę przez pryzmat heroicznych mitów, dlatego z dużym krytycyzmem odnosił się do opinii „humanistów”, ,pięknoduchów”, pacyfistów, słowem - wszystkich, którzy nie podzielali militarystycznych poglądów.

Przekonywał ich: „ta wojna jest koniecznością nieodpartą" ${ }^{\text {32 }}$.W jego wywodach zdroworozsądkowa ocena sytuacji przeplatała się z fatalizmem, z jednej strony jasno widział zagrożenia, jakie niosły ze sobą autorytarne rządy, z drugiej wybuch wojny postrzegał jako kolejny akt odwiecznego konfliktu polsko-niemieckiego. Był to zresztą węzłowy punkt dyskursu mocarstwowego, w którym Polska była przedstawiana jako ostatni „bastion prastarej kultury europejskiej - celtycko-słowiańskiej, bastion wystawiony na ciągłe ataki barbarzyńskich nordyków". Wywód historyczny przełamywał się często w opowieść mitograficzną, co wynikało z tego, że - jak przyznawał Grędziński - „nie możemy sobie rościć pretensji do ścisłości naukowej w pełnym znaczeniu tego słowa, bowiem niestety w tej dziedzinie nauka do dziś dnia jest na łasce i niełasce źródeł niemieckich «badaczy», którzy od wieków pracowicie i metodycznie posługiwali się świadomym i ordynarnym fałszem"33.

Polityka historyczna była dla niego walką narracji. Choć wyrażał nadzieję, że nadchodzi czas, gdy nauka polska zdemaskuje te "fałszerstwa”, to ze względu na tymczasowy brak dowodów przeniósł starcie w sferę mitów. W artykułach konstruował zakorzenioną w ideologii mocarstwowej kontrnarrację, odwołującą się do epoki jagiellońskiej, przedstawianej zazwyczaj

S. Grędziński Ładuj broń!, "Mocarstwowiec” 1932 nr 1.

Grędzisław Stasiński [S. Grędziński] Morze wenedyjskie, "Mocarstwowiec” 1931 nr 9. Tamże. 
w dość ogólnikowy, a niekiedy również anachroniczny sposób (jak choćby w rozważaniach o „mocarstwowej szkole obywatelskiej, która była zasadą ówczesnych obywateli państwa"34). Węzłowym punktem tej opowieści było zwycięstwo w bitwie pod Grunwaldem, gdy w otwartej walce rozbito siły odwiecznego wroga. Jego złowieszczy portret został odmalowany w artykule Krzyżacy, w którym Grędziński skupiał się tyleż na pobieżnym referowaniu kwestii historycznych oraz krytyce źródeł archiwalnych, co na budowaniu analogii pomiędzy dawnym zakonem a dążeniami „hitlerowców zwanych hackenkreuzlerami" ${ }^{35}$.

Spoiwem dyskursu mocarstwowego był antygermanizm. Nadawał kształt polityce historycznej, podsycał imperatyw ekspansji, czemu towarzyszyło hasło zbudowania od podstaw nowej polityki kulturalnej (łącznie ze zmianą hymnu narodowego). Grędziński narzekał na brak utworów literackich budujących mocarstwowego ducha, „nawet w piosence żołnierskiej”, pisał, „ani słowa, ani melodia nie zawierają nic ponad, w najlepszym razie, mdły zapach pachnącego groszku, w którym tak kochał się książę Pepi [...], poza tym: całe cysterny nudnej erotyki, pozbawionej zresztą również mocniejszych akcentów”36. W tej sytuacji na łamach "Mocarstwowca” odkurzano wzorce z wcześniejszego stulecia, publikowano fragmenty Krzyżaków Henryka Sienkiewicza oraz propagandowe teksty literackie, między innymi opowiadanie Grędzińskiego Reduta Piłsudskiego $0^{37}$ - wszystko to miało służyć wychowaniu młodzieży w duchu militarystycznym.

Analogiczny cel przyświecał powołaniu do życia „Młodego Mocarstwowca". W przeznaczonym dla młodzieży dodatku Grędziński propagował ideał społeczeństwa zorganizowanego na wzór hierarchii wojskowej, wysuwając na plan pierwszy imperatyw bezwarunkowego podporządkowania się Wodzowi oraz poleceniom przełożonych. W cyklu dydaktycznych artykułów pt. Rozkaz piętnował wszelkie zachowania indywidualistyczne, zapisując je na rachunek postszlacheckiej anarchii, za sprawą której „zamiast [...] nosić w sercu [...] najświętsze słowo Rozkaz, Polski rozkaz, [...] zaczęto uwielbiać inne słowo fałszywe, szatańskie - słowo Wolnośćn ${ }^{\prime 38}$. W ramach tej opozycji zdecydowanie

34 Tamże.

G. Stasiński [S. Grędziński] Krzyżacy, "Mocarstwowiec” 1931 nr 12.

36 S. Grędziński Ładuj broń!

37 S. Grędziński Reduta Piłsudskiego, „Mocarstwowiec” 1931 nr 10.

38 S. Grędziński Rozkaz, „Mocarstwowiec” 1931 nr 11. 
postępiał ideę samostanowienia jednostki, tak ważną dla dużej części myślicieli i pisarzy nowoczesnych, przeciwstawiających indywidualizm zorganizowanym i dehumanizującym systemom społecznym. Tymczasem dla Grędzińskiego rzecz przedstawiała się zgoła inaczej, największe niebezpieczeństwo upatrywał bowiem właśnie w nadmiernej niezależności; pisał: „prawego obywatela napełnia grozą pustki i przerażeniem śmierci myśl, że mógłby się choć na chwilę znaleźć poza obrębem zorganizowanej na rozkaz działalności społecznej, że mógłby

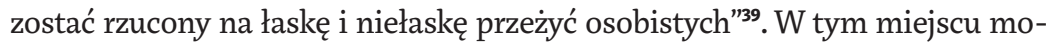
carstwowa idea monolitu społecznego wyraźnie przechylała się w stronę organizacji totalitarnej, co było jeszcze bardziej potęgowane przez militarystyczne idee, w myśl których podwładny powinien reagować na polecenia przełożonego w sposób automatyczny, niczym „ładunek ekrazytu w lufie karabinu”40. Z idei czynu wyparowywała tym samym romantyczna otoczka, odsłaniając ślepe podporządkowanie władzy przełożonych.

Sojusznikiem w tym surowym programie wychowawczym miał być katolicyzm. Grędziński widział w nim jeden z filarów mocarstwowej szkoły obywatelskiej, z uznaniem wypowiadał się o Kościele jako „niedoścignionym wzorze organizacji opartej o hierarchię, nie zaś o «wybory»” oraz „źródle siły i odwagi nieustraszonej w obliczu wroga"41. Był to naturalny sojusznik mocarstwowego państwa, które potrzebowało wyrazistego systemu uzasadnień dla prowadzonej przez siebie polityki, nawet jeśli owe uzasadnienia sytuowały się poza obszarem zdroworozsądkowej argumentacji. Dlatego z przekąsem pisał o „fałszywych przyjaciołach religii Chrystusowej, którzy wypaczali przy pomocy racjonalistyczno-humanitarystycznych koncepcji naukę Kościoła”, a jednocześnie przekonywał, że źródło siły religii bije gdzie indziej: „Demokratyzujący chrześcijanin, nie rozumiejąc ani dyscypliny Kościoła, ani irracjonalnego charakteru jego nauki, opiera się w swoich metafizycznych koncepcjach na tekstach Nowego Testamentu wedle swego racjonalistycznego widzimisię"42. W mocarstwowym dyskursie religia była narzędziem wspomagającym ideę bezwzględnego posłuszeństwa.

Dotyczyło to również praktyk biopolitycznych. Przyświecało im założenie, że niezbędnym elementem budowania imperium jest tresura

39

S. Grędziński Rozkaz (dokończenie), "Mocarstwowiec” 1932 nr 1.

S. Grędziński Ładuj broń!

S. Grędziński Katolicyzm jako szkoła obywatelska, "Mocarstwowiec” 1932 nr 2.

Tamże. 
ludzkiego ciała. Grędziński wiele uwagi poświęcił kwestiom wychowawczym, w artykule Uźródet mocarstwowej szkoty obywatelskiej pisał o konieczności uwzględnienia „naturalnych instynktów rasowych” oraz „braków i niedociągnięć psychiki narodowej”“3 , a jednocześnie postulował, by na ich podstawie stworzyć nowy program edukacji, który byłby rozpowszechniany wszystkimi metodami, jakimi dysponowało nowoczesne państwo. Rdzeniem tej koncepcji było hasło „Cały Naród pod bronią w bezustannym kontakcie z życiem wojskowym", które w praktyce sprowadzało się do postulatu jak najściślejszej współpracy wojskowych z cywilami, włączając w to nieletnich - Grędziński proponował, aby nauczanie przysposobienia wojskowego rozpocząć w przypadku harcerzy od siódmego roku życia, innych dzieci zaś - od czternastego. Służyć miało temu tworzenie hufców i batalionów zrzeszających młodych mocarstwowców, a także kształcenie ich na obozach o profilu sportowo-wojskowym. Integralnym elementem tych szkoleń były praktyki propagandowe, których wagę podkreślał Grędziński, zalecający wychowawcom, aby po każdych ćwiczeniach opiekun wygłosił słuchaczom przemówienie „o treści wybitnie mocarstwowej [...]. Będzie to kilka prostych prawd o Polsce, owianych dumą sztandaru armii, wygłoszonych z powagą i siłą, najlepiej dotyczące spraw bieżących: a. o niemieckiej bucie, b. - o rosnącej potędze Polski (wzrost ludności, flota powietrzna, kolej gdyńska itp.)"44.

W głoszonych przez Grędzińskiego hasłach o silnym państwie pobrzmiewały echa wcześniejszego o dwie dekady „momentu futurystycznego" (Perloff), który wytwarzał formy na przecięciu polityki i estetyki. W realiach włoskich skumulował się on w antytradycjonalistycznych hasłach Marinettiego, natomiast w Polsce - na co zwracał uwagę Tadeusz Peiper - przybrał inny kształt. W tym samym czasie kiedy we Włoszech rozpoczynali działalność futuryści, w polskiej kulturze coraz szerszy odzew zyskiwały antyromantyczne hasła, nawołujące do „oczyszczenia naszej atmosfery krajowej z sztucznych woni i środków usypiających, które już wtedy raniły prawdę zdrowych płuc"45. Marzenie to ziściło się poza obszarem sztuki, idea czynu została bowiem przeniesiona z dziedziny literatury do sfery polityki, a jej ucieleśnieniem stały się organizowane wtedy paramilitarne oddziały Związku Strzeleckiego;

S. Grędziński U źródeł mocarstwowej szkoły obywatelskiej, "Mocarstwowiec” 1931 nr 13.

44 Tamże. 
"Najgorętszą modlitwą tego czasu była modlitwa o wielki wentylator" ${ }^{46}$, pisał Peiper o atmosferze, jaka po 1910 roku towarzyszyła formowaniu się tych oddziałów. Zaciągnął się do nich również Grędziński, który po demobilizacji dalej prezentował się jako zwolennik „nowego”, najpierw jako skandalizujący futurysta, który podważał tradycyjne kanony estetyczne i normy moralne, a potem jako mocarstwowiec, przekreślający tradycyjny, „zmurszały” ład i wzywający do budowania podwalin nowoczesnego imperium. Wydaje się zresztą, że to właśnie doświadczenia wojskowe przesądziły o sporej różnicy między reprezentowaną przez niego wersją futuryzmu a postulatami, jakie głosili o kilka lat młodsi Anatol Stern, Aleksander Wat i Bruno Jasieński, którzy oglądali wojenne wydarzenia z nieco innej perspektywy. W ich twórczości nie było też tak wyraźnego sprzężenia pomiędzy aktywizmem, futuryzmem a militaryzmem, brakowało im również postawy propaństwowej, patronującej całej mocarstwowej publicystyce.

Łączyło ich natomiast z Grędzińskim znużenie przeszłością. Dlatego często pisali w prowokacyjnym tonie o wszechobecnych stęchliźnie, duchocie, braku słońca i tlenu, a jednocześnie nawoływali do oczyszczenia i przewietrzenia kultury, np. Bruno Jasieński wzywał: „Trzeba otworzyć na oścież wszystkie drzwi i okna, niech wywieje swąd piwnic i kościelnego kadzidła, którym od dziecka uczyli was oddychać. Zaopatrzeni w gigantyczne respiratory idziemy wam na spotkanie" ${ }^{47}$. Nowoczesna z ducha retoryka oczyszczania i porządkowania w wypadku autora Parabol miała inne konsekwencje, gdyż idea czynu została wyprowadzona poza obszar literatury, owocując relacjami między sztuką radykalnego modernizmu a polityką, które były częste nie tylko wśród futurystów włoskich i rosyjskich, lecz także polskich. O ile jednak w przypadku wielu rodzimych reprezentantów tego nurtu wiązało się to z akcesem ugrupowań lewicowych, o tyle Grędziński podążył w odmiennym kierunku, propagując wzorce militarystyczne i ekspansję kulturową. Jego publicystyka z początku lat 3o. dowodziła, że „wielki wentylator", który miał oczyścić kulturę ze zbędnych elementów, wciąż działał, ale został zwrócony w inną stronę.

46 Tamże, s. 149.

47 B. Jasieński Do narodu polskiego. Mańifest w sprawie natychmiastowej futuryzacji żyća, w: Antologia polskiego futuryzmu i Nowej Sztuki, red. H. Zaworska, Ossolineum, Wrocław 1978, s. 9. 


\section{Abstract}

\section{Aleksander Wójtowicz}

MARIA CURIE-SKŁODOWSKA UNIVERSITY (LUBLIN)

From Futurist to Imperialist: Stanisław Grędziński's Case

Wójtowicz analyses Stanisław Grędziński's literary and journalistic work to discuss the relationship between radical modernist art and the politics of the interwar era. The focus is on the transition from the futurist discourse to an imperialist discourse. Wójtowicz demonstrates how Grędziński's futurist rhetorics became enmeshed with the imperialist project with its relativist historical politics, an instrumentalisation of Catholicism, the militarisation of exercise and pedagogy, biopolitical practices as well as the slogan of cultural expansion.

\section{Keywords}

Stanisław Grędziński, futurism, avant-garde, Legia Mocarstwowa, imperialism 